\section{Re: Overbehandling, underbehandling eller riktig behandling?}

Takk til Hege Gjessing for å ha påbegynt en drøfting av de utfordrende dilemmaene rundt over- og underbehandling, og takk til kollega Gisle Roksund som tar ballen videre (1). Jeg fikk lyst til å «delta på en konstruktiv måte». Mitt utgangspunkt er fastlegekontoret, en god orkesterplass for hvordan disse fenomenene spiller seg ut.

Bør denne diskusjonen «avmedikaliseres» noe? Fenomenet medikalisering er svært komplekst, med røtter i dype kulturelle og politiske føringer. Medisinsk dokumentasjon alene vil ikke føre frem til fyldestgjørende forståelse. Videre medisinsk forskning vil kunne gi noen nye innsikter og oversikt, men vil kunne forsinke oss og blinde oss for andre perspektiver. Politiske analyser, verdidiskusjoner og definisjonsmaktanalyser må også til. Defineres bare tellekantkunnskap som grunnlag for kritikk av medikaliseringsepidemien, spilles det fort, paradoksalt nok, på bortebane i hver runde.

En viktig problemstilling i Gjessings leder er om forekomsten av usunn overbehandling er større enn forekomsten av underbehandling. Hvorfor er det viktig å sette disse fenomenene opp mot hverandre? Begge deler forekommer, og det ene kan være like galt som det andre. Et kritisk blikk på overbehandling øker ikke nødvendigvis risikoen for underbehandling. Tvert imot.

At diskusjonen om overbehandling bør føre til bekymring for legenes rykte som «lemfeldig», forstår jeg ikke. Tvert imot er det i denne diskusjonen vi kan demonstrere vår profesjonelle ryggrad og evne til god skjønnsforvaltning. Jeg ser knapt noen andre grupper som med raskere virkning kan starte et nødvendig avmedikaliseringsarbeid enn legene. I alle fall en debatt. Her må vi være på ballen!

Finnes det et medikaliseringsproblem? La oss ikke vente veldig mye lenger på bedre dokumentasjon og mer forskning. Med ydmykhet overfor hvordan ting fremstår i andre deler av helsevesenet, er dette min påstand: De fleste som jobber i førstelinjetjenesten, vil nikke gjenkjennende til ord som «forventningskrise» og «bekymringsepidemi» $\mathrm{Og}$, om vi liker det eller ikke: Fastlegene har en fremskutt rolle $i$ en sunn og nødvendig avmedikalisering av landet. Hvem har vi i ryggen? Forhåpentligvis vår egen legeforening.

\section{Harald Sundby}

har-su2@online.no

Harald Sundby (f. 1962) er fastlege og universitetslektor ved Kalvskinnet legesenter, Trondheim.

Ingen oppgitte interessekonflikter.

Litteratur

1. Gjessing $\mathrm{H}$. Overbehandling, underbehandling eller riktig behandling? Tidsskr Nor Legeforen 2014; 134: 577.

\section{Re: Overbehandling, underbehandling eller riktig behandling?}

Jeg er overrasket over denne lederen (1). Det er solid internasjonal dokumentasjon for å hevde at overdiagnostikk og overbehandling er en av de største utfordringene moderne vestlig medisin står overfor. Jeg vil i denne omgang nøye meg med å vise til min artikkel i Dagens Medisin om dette temaet (2). Ledende internasjonale tidsskrifter, bl.a. $B M J$, har viet temaet stor interesse i lang tid.

Jeg tror foreningen gjør klokt $\mathrm{i}$ å innse problemet og være i forkant med en diskusjon om hvilke tiltak som bør iverksettes. En lettvint politisk løsning med mindre bevilgninger til helsetjenesten generelt vil etter min oppfatning gå ut over fagligheten og det faglige arbeidet, og bør selvfølgelig søkes unngått. Men etter min oppfatning burde foreningen ta mål av seg til å lede an i diskusjonen og arbeidet, og ikke bare følge og delta i diskusjonen «på en konstruktiv måte».

\section{Gisle Roksund}

gisle.roksund@gmail.com

Gisle Roksund (f. 1951) er fastlege ved Klosterhagen legesenter

Ingen oppgitte interessekonflikter.
Litteratur

1. Gjessing H. Overbehandling, underbehandling eller riktig behandling? Tidsskr Nor Legeforen 2014: 134: 577 .

2. Roksund G. Ikke unødvendig, men likevel for mye. Dagens medisin, nettutgave. www.dagensmedisin.no/legeliv/legeliv-ikke-unodvendig-behandling-men-formye/ (17.3.2014)

\section{Re: Legers private henvisningspraksis}

Artikkelen fra Rådet for legeetikk refererer til en sak fra et akuttmottak, men handler reelt om fastlegeordningen (1). «Snarveien» som problematiseres gjelder gjerne henvisning til avdeling for øyeblikkelig hjelp. Den mottakende avdelingen er uenig med én eller flere leger om hvordan de henviser til øyeblikkelig hjelp, eller om henvisningene i det hele tatt er indiserte. Dermed er det et anliggende for avdelingen å ta fatt i sammen med henvisende lege(r) hva de oppfatter forskjellig, og hva det innebærer. Kollegialitet er et godt fundament for trygt å kunne være uenige om fag og praksis. Er dette å «påføre belastende konflikt»? Rådet kunne med fordel begrenset seg og hjulpet avdelingen til å benytte sitt kollegiale verktøy. En lang byråkratisk utlegning til allmenn støtte for fastleger og fastlegeordningen synes ganske overflødig og knapt til hjelp for noen.

All henvisning til videre helsehjelp er offentlig, siden legelisens er et høyst offentlig anliggende. Indikasjon for å henvise skal fylle de samme kriteriene om det gjelder deg selv eller pasienter, i praksis heller strengere om det er for deg selv. Jeg har hatt lisens i 54 år, hvorav 10 som distriktslege. Dermed har jeg vært betrodd noen tusen konsultasjoner og en god del henvisninger og innleggelser. I løpet av disse årene har jeg iblant henvist meg selv - antagelig også ved behov for øyeblikkelig hjelp. Behandling og forløp, samt epikriser, både for pasienter og meg selv, har i min oppfatning bekreftet en rimelig faglig indikasjonsstilling. Ikke i noen sammenheng har jeg erfart å bli behandlet annerledes enn pasientene. Fastlegeordningen har jeg brukt fra den kom, og jeg er blitt møtt og tatt vare på tilfredsstillende og dels mer enn det.

Så hvorfor henvise seg selv? For det første gjør det en forskjell å være lege. Ut fra det vil jeg, som ellers i hverdagen, gjerne ordne selv det jeg vet er nødvendig, og som jeg kan ta meg av. Minst like viktig er at jeg ikke vil be fastlegen om noe som vi begge vet jeg like greit kan utføre selv. Det blir et ubehagelig «late som» om vi bare utfører et påfunn uten faglig begrunnelse. Fastlegen får jo også tilsendt samme informasjon som når han selv henviser.

Her har jeg brukt meg selv som eksempel fordi jeg ikke har noe annet, og fordi jeg oppfatter min praksis med henvisninger som helt i tråd med det allmenne i det som har vært mine sammenhenger.

\section{Arnulf Gjestland \\ arnulf.gjestland@enivest.net}

Arnulf Gjestland (f. 1933) er pensjonert psykiater.

Ingen oppgitte interessekonflikter.

Litteratur

1. Hytten K. Legers private henvisningspraksis. Tidsskr Nor Legeforen 2014: 134: 435

\section{Re: Kvinne i 30-årene med kronisk utmattelse}

Artikkelen til Bjartveit og medarbeidere impliserer at kvinnen var feildiagnostisert (1). Tatt i betraktning den påvirkningen elektrokonvulsiv terapi (ECT) har på immunsystemet, er jeg ikke så sikker på det. Symptombedringen kan også forklares ved at elektrokonvulsiv terapi reduserer nivået av interferon-y (IFN- $\gamma)$, stimulerer 